\title{
Implementation of Education Management Standards Policy in The Medan City Education Departement Office
}

\author{
A.Pasaribu ${ }^{1}$, A.Rahman ${ }^{1}$, Z.Matondang ${ }^{1}$

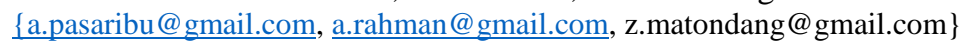 \\ Program Studi Administrasi Pendidikan, Pascasarjana, Universitas Negeri Medan ${ }^{1}$
}

\begin{abstract}
This study aims to find out how the support of communication, resources, disposition and structure of the bureaucracy and how is the consistency in implementing standard management policies in Education in the Medan City Education Office. These supports were obtained by observing, interviewing and studying documents at the Medan City Education Office, especially the head of the Primary and Secondary Education Division, and as a source of triangulation carried out also in elementary schools in Medan City. Selected SD Negeri Percobaan Medan, SDIT Al Fityan Medan, and also SDIT Al Munadi Medan. Interviews were conducted with the head of the Medan City Education Office in the Field of Primary and Secondary Education, head of the Medan Experimental Public Elementary School, Al Fityan Medan Elementary School, and Medan SDIT Al Munadi. Likewise, observation and documentation study. From the results of interviews, observations and documentation studies it was found that (1) communication aspects are less supportive of the element of information clarity, (2) aspects of resources have supported policy implementation, (3) the disposition aspect shows the support of the attitude of the apparatus in the school in carrying out a fairly good management standard policy, (4) aspects of the bureaucratic structure that are in accordance with the TUPOKSI are supplemented by SOP support in each school for certain needs.
\end{abstract}

Keywords: Implementation, policy, management, education, Medan

\section{Introduction}

Education is a joint process between the government as a determinant of policy in terms of quality and service standardization, the community as subjects who get education services and also third parties as users of the Education product. To achieve quality and quality education, a number of quality implementation components are needed starting from the implementation regulations, education and education personnel resources, curriculum, facilities and quality assessment systems. The government issued various policies as a rule in the implementation of education in this country. preceded by the issuance of the law, followed by government regulations as its operationalization, and so on until the issuance of SOPs (standard operating procedures) in schools in implementing various policies technically. Referring to the theme of long-term education development based on Law Number 17 of 2007 concerning the National Long-Term Development Plan (RPJPN) for 2005-2025. Alignment of 
the theme and focus of Education development at each stage is further formulated in the 20052025 Long Term National Education Development Plan (RPPNJP), as shown in table 1.

Management of Education especially Primary and Secondary Education is focused on children's character education. To realize the positive character there is what is called strengthening character education and child-friendly school programs. How do schools manage education that prioritizes character education, based on child-friendly schools by involving the participation of various formal and non-formal institutions? This study is intended to explore how communication support, resources, disposition or attitude of the apparatus and the structure of biroraksi and the consistency of the implementation of standard policies for the management of education in schools under the Medan City Education Office.

\subsection{Public Policy}

The definition of policy according to political scientist Carl Friedrich [1]:

Table 1. Theme of Educational Development 2005-2025

\begin{tabular}{cccc}
\multicolumn{4}{c}{ Table 1. Theme of Educational Development 2005-2025 } \\
\hline \multicolumn{4}{c}{ THEMES OF EDUCATION DEVELOPMENT } \\
\hline 2005-2009 & $2010-2014$ & $2015-2019$ & $2020-2024$ \\
Development & Service & Regional & International \\
Capacity Building & Strengthening & competitiveness & competitiveness \\
\hline
\end{tabular}

Is an action that leads to a goal proposed by a person, group, or government in a particular environment due to the existence of certain obstacles while seeking opportunities to achieve goals or realize the desired goal.

Knoepfel and his colleagues emphasized Friedrich's statement when they interpreted the policy as "a series of decisions or activities resulting from structured interactions between different actors, both public and private, who are involved in various ways in the emergence, identification and resolution of a problem defined politically as a public one "(a series of decisions or actions as a result of structured and repeated interactions among various actors, both public/government and private / private involved in various ways of responding, identifying and solving problems that politically defined as a public problem [2].

\subsection{Implementation of Public Policy}

Merilee S. Grindle [2] says that public policy is influenced by two major variables, namely the content of policy and the environment of policy implementation (context of policy). While Daniel A. Mazmanian and Paul A. Sabatier [3] stated that the success of public policy implementation was influenced by three groups of variables, namely the characteristics of the problem, the characteristics of policies / laws, and environmental variables. On the other hand, Van Meter and Van Horn [2] state that there are at least five variables that influence the implementation of public policy. Namely policy standards and objectives, resources, communication between organizations and strengthening activities, characteristics of implementing agents, and socio-economic and political conditions.

Daniel A. Masmanian and Paul A. Sabatier [4] explain the concept of implementation as understanding what actually happens after a program is declared valid or formulated is the focus of policy implementation attention, namely events and activities that arise afterwards ratification of public policy guidelines that cover both efforts to administer it and to cause real consequences or impacts on society or events. 
Edwards III, who said that the implementation of policy is part of the stages of the policy process that is between the preparation of policies and the consequences that can arise from the implementation of the policy [5]. According to Edward III, there are four aspects that influence the implementation of public policy, namely communication, resources, disposition or attitude of the implementer, and bureaucratic structure.

\subsection{Management Standards}

Management standards are one part of eight national education standards as stated in government regulation number 23 of 2013 concerning changes to government regulation number 19 of 2005 concerning national education standards. It is stated that national standards are the minimum criteria regarding the education system in all jurisdictions of the Unitary State of the Republic of Indonesia. There are eight national education standards, namely graduate competency standards, content standards, process standards, educator standards and education staff, facilities and infrastructure standards, management standards, financing standards, assessment standards.

Management standards are national Education standards relating to the planning, implementation and supervision of Education activities at the level of the Education unit, district/city, province, or national to achieve efficiency and effectiveness in the implementation of Education (PP No. 19 of 2005 concerning National Education Standards). States that management of education requires the realization of all management functions in administering education, including planning, organizing, actuating, and controlling. The components of the management standard based on Minister of Education Regulation No. 19 of 2007 is program planning, implementation of work plans, and evaluation [5].

\section{Methodology}

\subsection{Research subject}

The subject of this study consisted of the Head of the Medan City Education Office in the Field of Primary and Secondary Education as the main subject and as the supporting subject was the head of Medan Primary School 1 Experiment, head of the Al Fityan SDIT Medan, and Head of SDIT Al Munadi Medan.

\subsection{Data collection technique}

Data collection in this study uses interview, observation and document study techniques

\subsection{Data Analysis Techniques}

Data analysis techniques in this study used an interactive model consisting of data collection, data reduction, data presentation, drawing conclusions and verification..

\section{Results and Discussion}

This study describes the implementation of standardized education management policies in elementary schools under the Medan City Education Office based on the theory of public policy implementation formulated by C. Edwards III. 
The results showed that support for policy implementation was based on the theory of C. Edwards III on aspects of communication, resources, disposition / attitude of the apparatus, bureaucratic structure

\subsection{Communication}

Based on the results of observations, interviews, and also documents found by researchers during carrying out this research, the researcher draws conclusions related to communication that was built in implementing the policy regarding Education Management Standards in schools under the Education Office is already in accordance with the theory delivered by Edward III. Especially for the transmission aspect and also the consistency of the communication. What was built started from the Education Office, in this case the Head of the Basic Education Division to the elementary and lower school principals both public and private. Except for newly established schools, there are still those who have not received socialization and guidance directly from the Education office. Even though the supervisors at the sub-district level still get their guidance.

While for the aspect of clarity of information regarding management standards, it is less fulfilling considering there is no specific explanation and also technical guidance regarding the standard of management of basic education by the Medan City Education Agency. But in general, it is, namely, the National Education Standards where Education management standards are one of the standards contained in them.

\subsection{Resource}

Ipolicy implementation must be supported by supporting resources, such as human resources, methods of implementation, and material that is made into policy. Without adequate resource support, the policy product will be an administrative document that does not have an impact on the community. Resources that support the implementation of public policies include adequate staff, complete information, funding that includes all programs, structured authority, and other supporting facilities. (Affandi and Warjio in Ramdhani, 2016)

Based on the results of observations, interviews and document studies that the researchers did during carrying out this research it was found that the staff available to implement the management standard policy were quite numerous and fulfilled the expected competencies of the implementation of the management standard policies. The principals are technical executing officials at their respective schools who have a minimum education background of undergraduate degrees. In addition, the training carried out by the Education Office through sub-district supervisors and directly carried out by the Education Office can help school principals to implement the management standards in their schools to the fullest.

Availability of sufficient and easily accessible information on this management standard, although it is not obtained directly from the Education Office, but the school principals can directly access it via the internet and through discussion forums followed by the principal. This has led to the availability of information about the standard of Education management until the technical instructions for its implementation are easily obtained and applied by school principals. Although still, there must be guidance and direction from the Education Office, in a smaller capacity through school supervisors in each sub-district.

Funding provided by the government through BOS funds is considered to be still inadequate for the operations of all activities and programs run by schools. Therefore, principals based on the guidance and direction of the Education Office mobilize the potential and role of parents to help programs and activities in schools work hand in hand for the implementation of programs or activities designed by the school. By continuing to prioritize 
the principles of openness and cooperation, parents of students become more caring and prepared to help schools for the education of their children.

The authority attached to the Education office to force school principals to work in accordance with their Tupoks meet various administrative standards expected in Education management standards. Similarly, the authority of the head of school is to force teachers to work well in accordance with Tupoksi so that the implementation of Education management standards can run well. Good facilities are certainly one of the factors that support the implementation of policies regarding Education management standards. From the observations and also the results of interviews of researchers that elementary schools, both public and private, have begun to provide facilities to support the implementation of standardized Education management in their respective schools. Both in the form of facilities and infrastructure in schools are directed to support the successful implementation of management standards in schools.

\subsection{Disposition / Attitude of Apparatus}

Tendency is the attitude shown by the policy organizers in supporting the implementation of a policy. The better the attitude shown by the apparatus on a policy, the more real their support for the implementation of the policy will be in the form of the application of its work programs. On the contrary, the more different the attitude shown by the implementing apparatus, the more difficult the implementation of the policy will be [6-7]. Based on the results of the interview, observations during the observation the researchers found that the attitude shown by the staff starting from the principal and also the teachers in carrying out the programs that had been compiled looked very good and helped smooth it out.

Even though there are problems found after tracing more to the obstacle of communication that is clogged between one party and another. And after further clarification and explanation, usually the attitude that is raised is the attitude of support and cooperation so that the results obtained are also maximum. Coupled with exemplary and also an open attitude from the principals to the teachers makes the atmosphere of a more lively and vibrant work environment. The result is satisfaction from the teachers, students are well served, and of course parents as school partners feel the benefits directly to their children as a fruit of the process carried out in school.

\subsection{Bureaucratic Structure}

Basically, every policy implementer knows what must be done, has resources that support its implementation, but in its implementation, they are hampered by the organizational structure where they are required to implement the policy [8]. According to researchers, the implementation of management standards in schools under the Education Office is inseparable from the neat working structure of the organization. It is not merely the complex structure that is built, because it will be related to the availability of personnel at school. However, more to the division of work and the right responsibilities to the right people will have more influence on the successful implementation of these Education management standards at the school level as implementers. And this is in accordance with the theory put forward by Edwards, that the most important are people who know what, how, they will do to support work programs that are compiled, implemented and evaluated later. Few but understand working more effectively than many but don't understand what they want to do and how to do it.

Based on observations, interviews and study documents that the researchers did during the period of this study it was found that the principals always had a special team that helped various jobs in the field. And the right division of work to the right people is certainly done 
through a process that is not short, needing to change personnel several times to be given the right tasks and responsibilities. Until finally a solid, strong and precise team was formed.

\section{Conclussion}

Implementation of standardized management of education in elementary schools under the education office of the city of Medan in accordance with Minister of National Education Regulation No. 19 of 2007 concerning Management Standards for Primary and Secondary Education is supported by several factors. These include: (1) communication, (2) resources, (3) apparatus' attitude, and (4) bureaucratic structure.

Each supporting factor is related to one another, and which is used as a benchmark to assess the success and consistency of the implementation of education management standards for elementary schools under the Medan City Education Office whether or not it is in accordance with the policy direction.

\section{References}

[1] Bungin, Burhan (2007) Qualitative Research Second Edition. Jakarta: Kencana.

[2] Jaya, M., Aziz Satriya \& Dini Merianza. Resume Books Implementing Public Policy, Chapters 1-3 (George C. Edwards III). accessed on March 26, 2018 , <http://ratuagung78.blogspot.co.id/2011/05/resume-buku-implementing-public-policy.html>

[3] Miles, M.B., \& Huberman, A.M. (2009) Qualitative Data Analysis. Jakarta: UI-Press.

[4] Moleong, L.J. (2009) Qualitative Research Methods. Bandung: Teenager Rosdakarya.

[5] Moleong, L.J. (2016) Metodologi Penelitian Kualitatif (edisi revisi). Bandung : Remaja Rosdakaya

[6] Permendiknas Number 19 of 2007 concerning Management Standards. Jakarta: Ministry of Education and Culture

[7] Permendiknas Nomor 32 of 2013 concerning Amendment to Government Regulation Number 19 of 2005 concerning National Education Standards. Jakarta: Ministry of National Education

[8] Sugiyono (2012) Qualitative Quantitative Research Methods and R \& D. Bandung: Alfabeta. 